\title{
FORUM
}

Submitted 06.30.2016. Approved 01.16.2017

Evaluated by double blind review process. Scientific Editors: Adriana Roseli Wünsch Takahashi, Sergio Bulgacov, Claudia Cristina Bitencourt and Hale Kaynak

DOI: http://dx.doi.org/10.1590/So034-759020170304

\section{INNOVATION AND DYNAMIC CAPABILITIES OF THE FIRM: DEFINING AN ASSESSMENT MODEL}

\author{
Capacidades dinâmicas e de inovação da empresa: Definindo um modelo de \\ avaliação
}

\section{Capacidades dinámicas y de innovación de la firma: En búsqueda de un modelo de evaluación}

\begin{abstract}
Innovation and dynamic capabilities have gained considerable attention in both academia and practice. While one of the oldest inquiries in economic and strategy literature involves understanding the features that drive business success and a firm's perpetuity, the literature still lacks a comprehensive model of innovation and dynamic capabilities. This study presents a model that assesses firms' innovation and dynamic capabilities perspectives based on four essential capabilities: development, operations, management, and transaction capabilities. Data from a survey of 1,107 Brazilian manufacturing firms were used for empirical testing and discussion of the dynamic capabilities framework. Regression and factor analyses validated the model; we discuss the results, contrasting with the dynamic capabilities' framework. Operations Capability is the least dynamic of all capabilities, with the least influence on innovation. This reinforces the notion that operations capabilities as "ordinary capabilities," whereas management, development, and transaction capabilities better explain firms' dynamics and innovation.
\end{abstract}

KEYWORDS | Innovation capabilities, dynamic capabilities, firm, assessment model, innovative performance.

\section{RESUMO}

As capacidades dinâmicas e de inovação têm recebido considerável atenção, tanto na academia quanto na prática. Embora um dos mais antigos questionamentos da literatura econômica e de estratégia envolva a compreensão das características determinantes do sucesso comercial e da perpetuação da empresa, a literatura ainda carece de um modelo abrangente de capacidades de inovação e dinâmicas. Este estudo apresenta um modelo que avalia as perspectivas das capacidades de inovação e dinâmicas da empresa a partir de quatro capacidades essenciais: capacidades de desenvolvimento, operações, gerenciamento e transações. Dados de uma pesquisa com 1.107 empresas brasileiras de manufatura foram utilizados para a realização de testes empíricos e discussões sobre a estrutura das capacidades dinâmicas. Análises de regressão e fatoriais validaram o modelo; discutimos o resultado, contrastando com a estrutura de capacidades dinâmicas. A capacidade de operações é a menos dinâmica de todas as capacidades, com a menor influência em inovação. Isso reforça a noção das capacidades de operações como "capacidades ordinárias", enquanto as de gerenciamento, desenvolvimento e transações explicam melhor a dinâmica e a inovação das empresas.

PALAVRAS-CHAVE / Capacidades de inovação, capacidades dinâmicas, firma, modelo de avaliação, desempenho inovador.

\section{RESUMEN}

La innovación y las capacidades dinámicas han ganado considerable atención tanto en la academia como en la práctica. Mientras el entendimiento de las características que impulsan el éxito y la perpetuidad de la firma es una de las preguntas más antiguas en la literatura de economía y estrategia, aún falta un modelo amplio sobre capacidades de innovación y capacidades dinámicas. El artículo presenta un modelo de evaluación que operacionaliza una visión basada en las capacidades de innovación y capacidades dinámicas de la firma. El modelo se basa en cuatro capacidades esenciales (desarrollo, operación, gestión y transacción). Se realizó un survey con 1.107 firmas industriales brasileñas para probar empíricamente y discutir el modelo de las capacidades dinámicas. El análisis factorial y de regresión validaron el modelo. La capacidad de operación es la menos dinámica y con menor influencia en la innovación. Eso refuerza la noción de que la capacidad de operación es una "capacidad común", considerando que las otras capacidades explican mejor la dinámica de la firma.

PALABRAS CLAVE / Capacidades de innovación, capacidades dinámicas, firma, modelo, desempeño de innovación. 


\section{INTRODUCTION}

One of the oldest inquiries in economic and strategic management literature involves understanding the features that drive business success and a firm's perpetuity. Strategic management literature has progressed, moving from approaches based on industrial organization analyses (Bain, 1956; Porter, 1985) to those based on distinctive and core competencies (Prahalad \& Hamel, 1990; Snow \& Hrebiniak, 1980) and resource-based perspectives, among others (Barney, 1991; Penrose, 1959; Wernerfelt, 1984). However, innovation and the role of the firm has gained considerable attention since the neo-Schumpeterian views of economic change (Nelson \& Winter, 1982; Rosenberg, 1982) and Teece, Pisano, and Shuen's (1997) introduction of the dynamic capabilities concept. This is primarily because the nature of competitive advantage in fast-paced environments lies not only in the possession of specific, tangible assets (such as operational equipment and facilities), but in the firm's evolutionary ability to continuously redefine its technological and organizational boundaries and seize new market opportunities (Teece, 2007). The firm's capabilities, what Richardson (1972) called "knowledge, experience, and skills", are at the center of this process as well as the dynamic capabilities to "integrate, build and reconfigure internal and external resources/ competences to address and shape rapidly changing business environments" (Teece et al., 1997, p. 516).

While innovation may be the expected result of possessing dynamic capabilities, we still lack a comprehensive model that integrates dynamic capabilities and their effects on the firm's innovation performance. As expressed by Teece (2007), the concept of dynamic capabilities is: "[...] not designed to be comprehensive, but to integrate strategy and innovation literature and provide an umbrella framework to highlight the most critical capabilities management needs to sustain evolutionary and entrepreneurial fitness of the business enterprise" (p. 1322).

Nonetheless, the inability to design a comprehensive model raises important issues for research as to how to identify patterns of competitive innovation behaviors over time. Moreover, this undermines the possibility to build a coherent theory that follows specific testable hypotheses. Although Dynamic Capabilities and Strategic Management (Teece et al., 1997) is the most cited article in the Strategic Management Journal, it still faces strong criticism for still withstanding empirical tests and validation (Ambrosini \& Bowman, 2009; Arend \& Bromiley, 2009; Barreto, 2010). In fact, Eriksson (2014) notes that the tendency exists for qualitative research being conducted on dynamic capabilities, rather than quantitative, due to the complexity of the process.

This study aims to assess and undertake empirical testing and discussion of the dynamic capabilities framework and its relationship to innovation. We argue that it is necessary to identify and model the capabilities that actually drive firms' innovation performance in order to link dynamic capabilities to innovation. Therefore, dynamic capabilities underline the firm's innovation capabilities.

We do so by presenting the building blocks, assumptions, and validity of the firm's capability-based model, as developed by Zawislak, Alves, Tello-Gamarra, Barbieux, and Reichert (2012). This perspective posits that the firm functions based on four essential capabilities: development, operations, management, and transaction. These four capabilities broadly exist in any firm, although they vary in content, allowing firms to differ and develop their own paths (Nelson, 1991). Therefore, a general innovation capability model based on these four main capabilities facilitates the operationalization and measurement of their impact on innovation. We assume that these capabilities are dynamic in nature, and vary in their intensity over innovation.

After defining the theoretical model, 1,107 Brazilian manufacturing firms were surveyed. Innovation measurements should consider how these internal capabilities contribute to the firm's innovation performance.

\section{Linking the firm's innovation and dynamic capabilities}

Dynamic capabilities are a research field that seeks to understand why one firm outperforms another. Teece et al. (1997) propose a framework to capture how any firm entrepreneurially manages its different resources to outperform the competition. The authors' classically define dynamic capabilities as "the ability to integrate, build and reconfigure internal and external resources/ competences to address and shape rapidly changing business environments" (Teece et al., 1997).

According to Winter (2003), dynamic capabilities enable the firm to operate, extend, modify, and create ordinary abilities. Moreover, they can change the firm's resource base to obtain a sustainable competitive advantage (Ambrosini \& Bowman, 2009; Helfat et al., 2007). Innovation in this sense seems to originate as a logical positive outcome from the possession of dynamic capabilities; from this point of view, dynamic capabilities should be perceived as innovation-driven. However, this conceptual link is not explicit, as Barreto (2010) defines dynamic capabilities as the firm's potential to systematically solve problems based on its propensity to sense opportunities and make timely marketoriented decisions.

While innovation is implicit across the various definitions of dynamic capabilities, this study argues that innovation should be made explicit, for it is the sole source of comparative 
advantage to sustain a firm's perpetuity. The challenge involves identifying and measuring the various ways firms' innovation occurs. According to Brezinik and Hisrich (2014), the concept of innovation capabilities is complementary to that of dynamic capabilities, based on a Schumpeterian view of competition. We see and demonstrate that dynamic capabilities are a precursor to innovation capabilities. The primary task in this sense is to identify the capabilities needed for innovation to clarify dynamic capabilities' role in innovation.

\section{In search of an innovation and dynamic capabilities' model}

We design a comprehensive model of firms' innovation and dynamic capabilities by first defining the firm as technological set of products and processes that operates under a specific business model to transact with and profit from the market. This is, in other words, a pool of knowledge, assets, and capabilities that must be orchestrated to fulfill specific market gaps. In this sense, and underlying any business activity, a certain set of general capabilities exists that must be assembled to address technoeconomic problems.

Previous approaches have focused on the innovative firm's technological capabilities (Lall, 1992), or specifically, “on the capabilities needed to generate and manage technical change" (Bell \& Pavitt, 1995, p. 78). While this is a relevant dimension innovation (Saphia et al, 2016), if one exclusively interprets innovation as the outcome of scientific and technological advances, the spectrum of how change and innovation occur in the vast majority of firms may be unclear. Beyond technology, innovation is the result of the successful choice of a business model that includes the decision, over a combination of assets and capabilities that may be available for purchase or that must be built inside of the firm (Teece, 2007).

According to Dosi et al. (2000), dynamic capabilities cannot simply be built by sole investment in research and development (R\&D). As the competitive pace quickens, coordination between R\&D and the firm's other functions, as well as with suppliers and alliance partners, is increasingly essential to identify and link technological options to market opportunities (Dosi et al., 2000). This highlights the importance of coordination and transaction capabilities as complements to technological capability (TelloGamarra \& Zawislak, 2013). If technological capabilities emphasize $R \& D$ and operations, then dynamic capabilities highlight the importance of management and strategy (Dutrénit, 2000).

Technology as the application knowledge into products and processes can only be successfully accomplished if firms can make it economically feasible. Therefore, firms should discover a balance between their technological and organizational capabilities to make business possible.

\section{The innovation capabilities model}

As previously discussed, the firm is viewed as a technological set of product and process that operates under a specific business model to transact with and profit from the market. Therefore, every firm to some extent has the following general capabilities: development, operations, management, and transaction (Figure 1). These cover the key aspects underlying any firm's existence.

\section{Figure 1. A capability-based model of firm innovation}

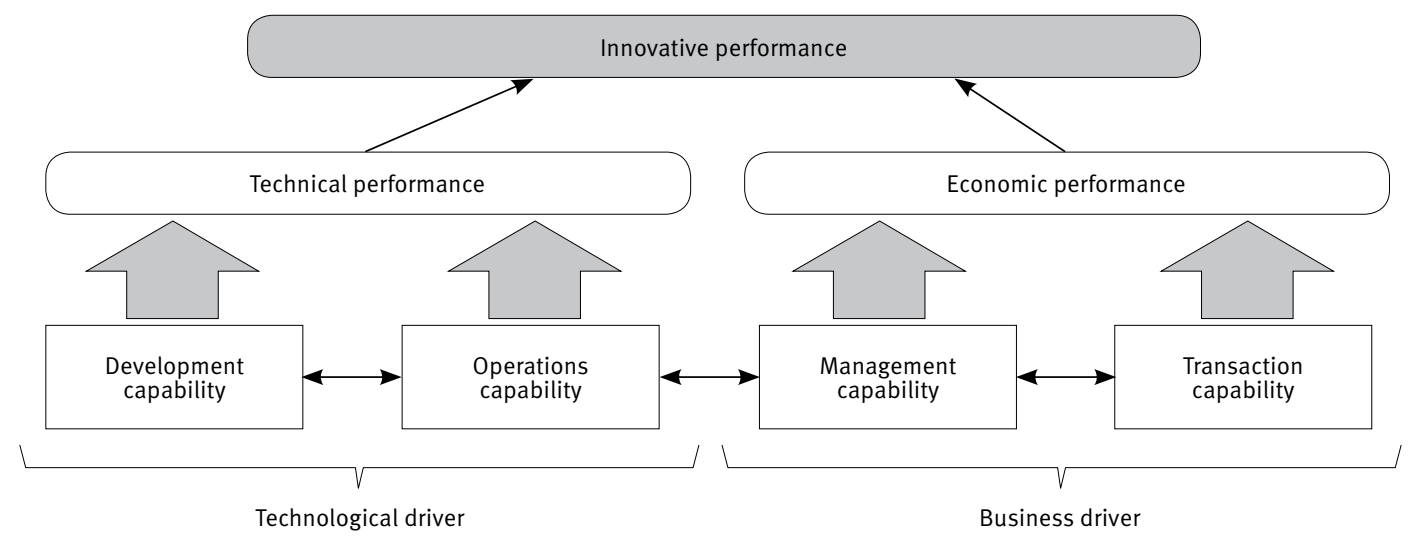

Source: Adapted from Zawislak et al. (2012, 2013). 
One can observe that these capabilities are grouped into two main drivers: technological and business drivers. The technological driver, or the development and operations capabilities, posits that every firm is born as a technical result of some sort of knowledge base, applied as an operational set of processes to transform resources into products, such as goods or services. The technological driver follows the rationale suggested by the technological capability approach (Bell \& Pavitt, 1995; Lall, 1992), which emphasizes firms' need to develop capabilities not only to generate and manage technical change (i.e., development), but also to use technology (i.e., operations).

Development capability (DC) is the ability to sense technological options and decipher novel market solutions by scanning, creating, learning, and interpreting different signals. This knowledge must then be translated to a specific operations capability with processes and routines (Nelson \& Winter, 1982). Further, DC enables the firm to develop and change, but to do so, firms must first absorb and internalize new knowledge to be applied in new processes and products. This requires efficient search routines and the ability to change, create, and recreate operations, which Teece (2007) notes is a dynamic capability. Technology development results in new products and processes, established in a firm's new technical and operational standards.

However, it is insufficient to merely develop new products, as these products should reach the market with quality and within a competitive price range. This can only be achieved through the operations capability (OC). Every firm has a certain operations level that arises from the selection of competitive priorities to exploit low costs, quality, delivery times, responsiveness, and flexibility (Hayes \& Pisano, 1994; Skinner, 1969; Wu, Melnyk, \& Flynn, 2010). Moreover, Lall (1992) mentions such activities as quality control, preventative maintenance, and workflow and inventory controls, among others. These often compound into a set of operational "best practices" to guarantee a smooth flow of solutions from development to delivery across a firm's value chain. These capabilities are about “doing things right" (Teece, 2014).

However, while important, $\mathrm{OC}$ is not often considered a dynamic capability. Teece (2007) argues that the adoption of "best practices" is not likely to be a dynamic capability, and especially if other firms widely adopt them. These may be characterized as "ordinary capabilities” (Winter, 2003). According to Ward, McCreery, Ritzman, and Sharma (1998), operations are concerned with the degree of product standardization, size of the product mix, and the volumes required; as well as production lead-time and the ability to attend to the market's required technological innovation. Once operations are heavily routine-based, their traits may create barriers to imitation, thus becoming potential sources of competitive advantage (Wu et al., 2010). Nevertheless, we separate these from development.
Every firm needs a business driver (management and transaction capabilities) to transport technical solutions to the market following the lead of the technological driver, in which only DC and OC are collectively responsible for offering technical solutions to potential markets. This driver decides what the firm will efficiently conduct in-house, and what it will outsource to the market, from both its supplier and clients. If technology gives the firm a path, business gives it a reason.

The firm must guarantee that the right things will "get done," and therefore, should have the specific ability to coordinate assets and activities; management capability (MC) is responsible for this task. Trott (2008) argues that "the task of all managers is to improve their operations-otherwise they are supervisors and do not justify their job title" (p. 119). If capabilities can be explained by a set of routines embedded in applied knowledge (technology), $M C$ requires a more generalist repertoire to act through choice and decision where technology fails to have a perfect routine. Management's capabilities require a wide range of skills, which should be flexibly applied in problem-solving to cope with various and often unpredictable circumstances (Langlois, 2003). From strategic decision-making to resource allocation, and through system integration, HR management, and accounting and finance issues, MC internally coordinates the firm. Nonetheless, management must be constantly aware of the process of change to dynamically adjust the organization to the firm's needs without falling into excessive control that may stifles change (Pufal, Zawislak, Alves, \& Tello-Gamarra, 2014).

Finally, the firm must bring to the market whatever it develops, operates, and manages in order to generate economic value. Thus, once a firm has developed a technological solution, it must do anything for favorable transaction and sales. As every firm uses, manages, and operates a given technology with the explicit goal of obtaining positive economic returns, it should have specific capabilities to actually trade its products. Outsourcing, customer relationships, negotiations and contracting, marketing and branding, and logistics and delivery, among others, compound the set of specific skills, routines, and systems to trade. Profiting from innovation involves finding the sources of complementary assets and channels necessary to bring technological development to the market (Teece, 1986). Additionally, there exists a moderating role between R\&D and marketing capabilities to firm performance (Kotabe et al. 2002). Firms exist as they can figure out ways of bringing valuable solutions more efficiently than what can be found in market. In this sense, they must continuously scan for information in the market and search for ways to reduce transactions costs (Coase, 1937; Williamson, 1985). These activities are collectively referred to as the transaction capability (TC). 
The way a firm combines and uses these different capabilities allow it to go beyond the simple application of "best practices" or "doing things right", to dynamically scan and decide over new combinations of knowledge and assets to bring novelty to the markets. In order words, innovation capabilities as dynamic capabilities are about “doing the right things" (Teece, 2014).

\section{Innovation capabilities' measures}

Most studies on innovation capabilities focus on technological innovation. These innovations are the result of technological and new product development capabilities that require a proper innovation strategy (Vicente, Abrantes, \& Teixeira, 2015). Nonetheless, different firms may present different types of innovation throughout their life cycles. Not all firms reach a technological frontier, but other innovation types derived from the other capabilities may explain their marketplace successes.

Innovation may come from new technologies, methods, production techniques, management and business models, as well as transactional strategies. This parallels the types of innovation suggested by Schumpeter (1934) and other authors, such as Francis and Bessant (2005) and the Organization for Economic Co-operation and Development Oslo Manual (2005), which typically include product, process, organizational, and marketing innovations.

According to Schumpeter (1934), innovation must necessarily lead to extraordinary profits for the innovator. This view poses some difficulties in gathering the necessary data to convey precisely whether any extraordinary profit is a result of specific changes by the firm due to firms' complexities and dynamics. Dynamic capabilities similarly seek to generate Schumpeterian returns. Teece (2010, p. 692) argues that dynamics capabilities aim to generate abnormal returns. All of a firm's actions (new product developments, processes, managerial arrangements, or commercial relationships) are intended to improve economic performance, such as sales increases or cost reductions; in other words, increases in profits. Therefore, a firm's innovative performance is a function of its development, operations, management, and transaction capabilities.

Innovation is the result of any of its capabilities, or a combination thereof, depending on firms' internal resources and market conditions. From this perspective, one should expect new products, processes, organizations, or transaction actions as novelties that could outperform the market's existing technical and economic value solutions and generate extraordinary profits. This Schumpeterian way of understanding a firm's dynamics and success draws on the shape of its innovative performance. Our hypothesis is derived from this discussion:
$\mathrm{H}$ : Innovative performance is impacted by development, operations, management, and transaction capabilities.

This model captures dynamic capabilities' effects on innovation by combining such capability measurements as processes and routines with an innovation performance (IP) outcome, measured as economic gains in terms of increase in profits, sales and market-share.

The following equation relates IP with minimum industrial standards ( $\beta 0)$, namely, the minimum technical, legal, and economic requirements to compete in a given industry; and the impacts of different innovation capabilities.

$$
I P=\beta_{0}+\beta_{1} D C+\beta_{2} O C+\beta_{3} M C+\beta_{4} T C+e
$$

Each capability (CD, CO, CG, or CT) has a standardized coefficient (respectively, $\beta_{1}, \beta_{2}, \beta_{3}$, and $\beta_{4}$ ). This combination of coefficients will precisely determine the arrangement of capabilities and, for the purpose of determining the role of these dynamic capabilities, the relative importance of each.

Exhibit 1 illustrates this study's definitions and proposed measures to understand how different firms cope with the challenges in perpetuating themselves over time.

\section{METHODOLOGICAL PROCEDURES}

This study seeks to test and to explain which firm capabilities are dynamic and relate to innovation. A factor analysis was performed to validate the instrument and construct. The hypothesis, which states that innovation depends on capabilities, was tested through a regression analysis.

\section{Sample and procedures}

This study proposes an assessment model of both innovation and dynamic capabilities. We test this model by using a database of 1,107 firms from an innovation survey conducted by the Innovation Research Center (NITEC, 2015), which evaluated the four innovation capabilities of firms from all 22 manufacturing sectors across Brazilian industries.

Brazilian manufacturing firms are generally from low-tech intensity sectors, as Table 1 illustrates; approximately $75 \%$ are considered low or medium-low intensive. Approximately $90 \%$ of the sample firms are characterized as small, and $89 \%$ are family managed, with $83 \%$ focused on operations, and thus, on costbased strategies (NITEC, 2015). In this context, these firms react in terms of both new product development and market requirements (Reichert, Camboim, \& Zawislak, 2015). 


\section{Exhibit 1. (Dynamic) Capabilities of the firm: Innovation and measured items}

\begin{tabular}{|c|c|c|c|c|}
\hline \multirow{2}{*}{ 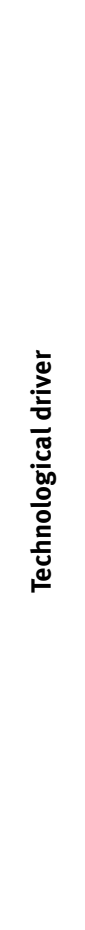 } & $\begin{array}{l}\text { Development } \\
\text { capability (DC) } \\
\text { Any firm's ability to in- } \\
\text { terpret the current state- } \\
\text { of-the-art, absorb, and } \\
\text { eventually transform a } \\
\text { given technology to cre- } \\
\text { ate or change its opera- } \\
\text { tions capacity; and any } \\
\text { other capability aiming } \\
\text { to reach higher levels } \\
\text { of technical-economic } \\
\text { efficiency. }\end{array}$ & $\begin{array}{l}\text { DC1. Ability to design its own products } \\
\text { DC2. Monitoring of latest tendencies in } \\
\text { technology in the sector } \\
\text { DC3. Use of formal product management } \\
\text { methods (Stage-Gate, PMBOK, } \\
\text { innovational funnel, etc.) } \\
\text { DC4. Ability to adapt the technology in use } \\
\text { to its own needs } \\
\text { DC5. Ability to prototype of own products } \\
\text { DC6. Development of products in } \\
\text { partnerships with science and } \\
\text { technology institutions } \\
\text { DC7. Ability to launches its own products }\end{array}$ & $\begin{array}{l}\text { Lall (1992); Bell } \\
\text { and Pavitt (1995); } \\
\text { Saphia et al. } \\
\text { (2016); Teece et } \\
\text { al. (1997); Teece } \\
\text { (2007). }\end{array}$ & $\begin{array}{l}\text { Teece et al. (1997) comment regarding the } \\
\text { observation of rate and direction, which } \\
\text { relevant scientific frontiers are pointing } \\
\text { to, and how the firm can learn and recon- } \\
\text { figure its technological path. The dynam- } \\
\text { ic capability framework emphasizes the } \\
\text { ability to sense technological and mar- } \\
\text { ket opportunities by "scanning, creating, } \\
\text { learning, and interpreting" technological } \\
\text { and market signals (Teece, 2007). }\end{array}$ \\
\hline & $\begin{array}{l}\text { Operations capability } \\
\text { (OC) } \\
\text { The ability to perform to } \\
\text { the given productive ca- } \\
\text { pacity through the col- } \\
\text { lection of daily routines } \\
\text { that are embedded in } \\
\text { knowledge, skills, and } \\
\text { technical systems at a } \\
\text { given time. }\end{array}$ & $\begin{array}{l}\text { OC1. Use of formalizes PPC procedures } \\
\text { OC2. Use of statistical control of processes } \\
\text { OC3. Use of leading edge technology in the } \\
\text { sector } \\
\text { OC4. Ability to maintain of adequate stock of } \\
\text { materials for processes } \\
\text { OC5. Ability to conduct the production } \\
\text { process as programmed } \\
\text { OC6. Ability to establishment production } \\
\text { routines that do not generate rework } \\
\text { OC7. Ability to promptly deliver the product } \\
\text { OC8. Ability to manage the expansion of the } \\
\text { installed capacity whenever necessary } \\
\text { OC9. Ability to ensure the process does not } \\
\text { lead to products' return }\end{array}$ & $\begin{array}{l}\text { Hayes and Pisano } \\
\text { (1994); Ward et al. } \\
\text { (1998); Skinner } \\
\text { (1969); Teece et } \\
\text { al. (1997); Teece } \\
\text { (2007). }\end{array}$ & $\begin{array}{l}\text { Teece et al. (1997) describe factors of } \\
\text { production and resources, and routines } \\
\text { and processes as elements of the frame- } \\
\text { work; however, in a globalized economy } \\
\text { this may not necessarily be conducted } \\
\text { inside the same firm that developed the } \\
\text { solutions. Operations are heavily rou- } \\
\text { tine-based, and are often not considered } \\
\text { a dynamic capability. As Teece (2007) } \\
\text { argues, the adoption of "best practices" } \\
\text { are not likely a dynamic capability, and } \\
\text { especially if they are widely adopted by } \\
\text { other firms. }\end{array}$ \\
\hline \multirow{2}{*}{ 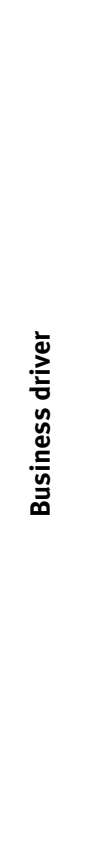 } & $\begin{array}{l}\text { Management } \\
\text { capability (MC) } \\
\text { The firm's ability to trans- } \\
\text { form the technological } \\
\text { outcome into a coherent } \\
\text { operational and transac- } \\
\text { tional arrangement. }\end{array}$ & $\begin{array}{l}\text { MC1. Use of formally defines its strategic } \\
\text { aims annually } \\
\text { MC2. Use of technology to integrate all its } \\
\text { sectors } \\
\text { MC3. Use of internal standards and } \\
\text { documents for work procedures } \\
\text { MC4. Updated management tools and } \\
\text { techniques } \\
\text { MC5. Maintenance of adequately trained } \\
\text { personnel for the company's functions } \\
\text { MC6. Use of modern financial management } \\
\text { practices }\end{array}$ & $\begin{array}{l}\text { Penrose (1959); } \\
\text { Mintzberg (1973); } \\
\text { Chandler (1977); } \\
\text { Zawislak et al. } \\
\text { (2012, 2013); } \\
\text { Teece et al. } \\
\text { (1997); Teece } \\
\text { (2007). }\end{array}$ & $\begin{array}{l}\text { Teece et al. (1997) perceive management } \\
\text { as playing three roles: coordination and } \\
\text { integration (static), learning (dynamic), } \\
\text { and reconfiguration (organization and } \\
\text { managerial processes). Eisenhardt and } \\
\text { Martin (2000) view dynamic capabilities } \\
\text { as essentially organizational processes. } \\
\text { Teece (2007) observes that management } \\
\text { is important dynamic capability in the } \\
\text { task of identifying, developing, and uti- } \\
\text { lizing a combination of specialized and } \\
\text { co-specialized assets, whether built or } \\
\text { bought. Teece (2007) calls for entrepre- } \\
\text { neurial management. }\end{array}$ \\
\hline & $\begin{array}{l}\text { Transaction capability } \\
\text { (TC) } \\
\text { The ability to reduce mar- } \\
\text { keting, outsourcing, bar- } \\
\text { gaining, logistics, and } \\
\text { delivering costs; in oth- } \\
\text { er words, transactional } \\
\text { costs. }\end{array}$ & $\begin{array}{l}\text { TC1. } \begin{array}{l}\text { Conduction of formal research to } \\
\text { monitor the market }\end{array} \\
\text { TC2. Ability to impose its negotiating terms } \\
\text { on its suppliers } \\
\text { TC3. Ability to impose its prices on the } \\
\text { market } \\
\text { TC4. Ability to impose its negotiating terms } \\
\text { on its customers } \\
\text { TC5. } \begin{array}{l}\text { Conduction of research to measure its } \\
\text { customers' satisfaction }\end{array} \\
\text { TC6. Use of formal criteria to select its } \\
\text { suppliers }\end{array}$ & $\begin{array}{l}\text { Coase (1937); } \\
\text { Williamson } \\
(1985) ; \text { Cannon } \\
\text { and Hamburg } \\
\text { (2001); Kotabe et } \\
\text { a. (2002); Mayer } \\
\text { and Salomon } \\
\text { (2006); Zawislak } \\
\text { et al. (2012, } \\
\text { 2013); Teece et } \\
\text { al. (1997); Teece } \\
(2007) \text {. }\end{array}$ & $\begin{array}{l}\text { A key aspect to define firms' position in- } \\
\text { volves deciding where to position orga- } \\
\text { nizational boundaries. Market structures } \\
\text { continuously change; therefore, the task } \\
\text { of positioning is dynamic. Reputational } \\
\text { assets must be built and strengthened, } \\
\text { which contributes to market power. }\end{array}$ \\
\hline 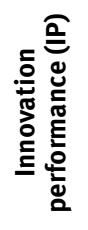 & $\begin{array}{l}\text { The new products, pro- } \\
\text { cesses, equipment, or- } \\
\text { ganizational forms, and } \\
\text { commercial market ap- } \\
\text { proaches that lead to } \\
\text { extraordinary profits. }\end{array}$ & $\begin{array}{l}\text { IP1. Growth in net profits over the last three } \\
\text { years } \\
\text { IP2. Growth in company's market share has } \\
\text { over the last three years } \\
\text { IP3. Growth in company's revenue over the } \\
\text { last three years }\end{array}$ & $\begin{array}{l}\text { Schumpeter } \\
\text { (1934); Francis } \\
\text { and Bessant } \\
\text { (2005); OECD } \\
\text { (2005); Eriksson } \\
\text { (2014). }\end{array}$ & $\begin{array}{l}\text { Schumpeter argues that innovation leads } \\
\text { to extraordinary profits (or rents). Teece } \\
\text { et al. (1997) asserts that dynamic capabil- } \\
\text { ities seek the generation of Schumpeteri- } \\
\text { an rents that come from innovation. "The } \\
\text { goal of dynamic capabilities is to generate } \\
\text { abnormal returns" (Teece, 2010, p. 692). }\end{array}$ \\
\hline
\end{tabular}

Source: Adapted from Zawislak et al. (2013). 
Table 1. Sample distributions by industry in the final survey

\begin{tabular}{|c|c|c|}
\hline Industry sectors & Sample & Percent \\
\hline Metal products & 136 & 12.3 \\
\hline Machinery \& equipment & 125 & 11.3 \\
\hline Footwear and leather & 116 & 10.5 \\
\hline Food & 108 & 9.8 \\
\hline Furniture & 92 & 8.3 \\
\hline Plastic and rubber & 86 & 7.8 \\
\hline Clothing & 70 & 6.3 \\
\hline Automotive & 50 & 4.5 \\
\hline Chemicals & 45 & 4.1 \\
\hline Wood & 43 & 3.9 \\
\hline Non-Metal products & 41 & 3.7 \\
\hline Diverse & 31 & 2.8 \\
\hline Electric & 27 & 2.4 \\
\hline Pulp and paper & 24 & 2.2 \\
\hline Printing & 21 & 1.9 \\
\hline Metallurgy & 19 & 1.7 \\
\hline Electronics & 13 & 1.2 \\
\hline Machinery maintenance & 12 & 1.1 \\
\hline Textiles & 12 & 1.1 \\
\hline Missing & 11 & 1 \\
\hline Beverage & 9 & 0.8 \\
\hline Tobacco & 7 & 0.6 \\
\hline Transportation equipment & 6 & 0.5 \\
\hline Petroleum refining & 2 & 0.2 \\
\hline Pharmaceuticals & 1 & 0.1 \\
\hline Total & 1,107 & 100 \\
\hline
\end{tabular}

\section{Survey protocol}

The survey instrument is a questionnaire written and applied in Portuguese, following Churchill's (1979) suggested procedures for developing superior measures. Protocol questions were organized in two blocks, with the first block divided into four parts. Each relates to one of the four capabilities: development (DC), operations (OC), management (MC), and transaction (TC). This block intends to assess each firms' innovation and dynamic capabilities and capture the existence of the routines and specificities by using an interval scale, from one to five, to measure the degree to which respondents agreed with the statements related to each capability. The second block measures change and innovation by also using an interval scale, from one to five, to measure the degree to which firms agreed with the types of changes and increase in economic indicators over the previous three years. Questions from this second block were used to create the innovation performance (IP) variable. The final questions regarding the main constructs are displayed in third column of Exhibit 1 in the next section.

Professional interviewers collected data through computerassisted telephone interviewing with either the firm's owner, president, directors, or top managers. All tests were performed using IBM SPSS Software for Windows, version 20.

\section{Instrument validation, tests, and regression}

First, we verified each of the five main constructs' internal consistency, as noted in Table 2. A Cronbach's alpha coefficient was used to verify the reliability of the data used as dimensions of the innovation capability model. This measures the correlation between questionnaire responses by analyzing the respondents' answers, with an average correlation between questions.

\section{Table 2 . Reliability statistics}

\begin{tabular}{l|c|c}
\hline \multicolumn{1}{c|}{ Capabilities } & Cronbach's alpha & N of Items \\
\hline DC & 0.845 & 6 \\
\hline OC & 0.796 & 5 \\
\hline MC & 0.793 & 5 \\
\hline TC & 0.758 & 4 \\
\hline IP & 0.843 & 3 \\
\hline Total & 0.879 & 20 \\
\hline$N=1,107$ & & \\
\hline
\end{tabular}

All coefficients were above the threshold values of 0.6 (ranging from o to 1) as suggested by Hair, Tatham, Anderson, and Black (2005) and Malhotra (2006), and 0.7 as suggested by Kline (1998) for acceptable levels of reliability. The IP demonstrated an equally high alpha value (0.843). The entire model considers all five elements and presented a high alpha coefficient (0.879), which confirms the reliability of the variables used as components of the innovation capability model.

We test the data quality by first performing statistical tests with all variables from the constructs. We ran the following tests: a reliability test, using Cronbach's alpha and a factor analysis; a 
Kaiser-Meyer-Olkin measure of sampling adequacy (KMO) to check for both validity and adequacy; and Pearson correlations, related to the firms' capabilities and performance. Variables were then grouped after the factor analysis and reduced into smaller groups. The same statistical tests were produced with these new variables to check improvements in the analysis. Factor loading scores were then used in the regression analysis, as displayed in the Results section.

\section{RESULTS, ANALYSIS, AND DISCUSSION}

\section{Finding the boundaries within innovation capabilities}

We verify and test the existence of the firms' different capabilities and their influence on innovation performance by first testing the presence of clear boundaries between capabilities using a factor analysis for construct validation. First, we performed a KMO test; values less than 0.5 would indicate weak correlations between the variables and result in an unsatisfactory factor analysis (Pestana \& Gageiro, 2003). We have also performed Bartlett's test to identify the absence of correlations between the variables, and a communalities analysis, which measures the variance proportion of one variable to the others.

We verified the adequacy by using a factor analysis, and discovered a $\mathrm{KMO}=0.905$ for sampling adequacy, or a "very good" correlation according to Pestana and Gageiro (2003). The Bartlett's test results were significant ( $p<0.001$ ), indicating that the data is fit for a factor analysis. We could then conduct the factor analysis, and to obtain the final model, we first ran a factor analysis without restricting the number of factors. We then excluded variables that presented values less than 0.5 , and tested whether the total variance explained increased. Finally, we used a component matrix Varimax rotation (Table 3).

\section{Table 3. Factor analysis}

\begin{tabular}{|c|c|c|c|c|c|}
\hline \multicolumn{6}{|c|}{ Rotated component matrix } \\
\hline$N=1,107$ & & 1 & 2 & 3 & 4 \\
\hline $\mathrm{DC}_{5}$ & Prototypes its own products & 0.761 & & & \\
\hline DC7. & Launches its own products & 0.759 & & & \\
\hline DC2. & Monitors the latest tendencies in technology in the sector & 0.689 & & & \\
\hline $\mathrm{DC}_{3}$. & Uses formal product management methods (Stage-Gate, PMBOK, innovation funnel, etc.) & 0.643 & & & \\
\hline $\mathrm{DC}_{4}$. & Adapts the technology in use to its own needs & 0.625 & & & \\
\hline MC6. & Uses modern financial management practices & & 0.753 & & \\
\hline$M C_{5}$ & Maintains personnel adequately trained for the company's functions (training) & & 0.646 & & \\
\hline$M C_{3}$ & Standardizes and documents work procedures & & 0.620 & & \\
\hline OC7. & Promptly delivers the product & & & 0.752 & \\
\hline OC9. & Manages to ensure the process does not lead to products' return & & & 0.745 & \\
\hline oc6. & Establishes a productive routine that does not generate rework & & & 0.743 & \\
\hline $\mathrm{OC}_{5}$ & Conducts the production processes as programmed & & & 0.675 & \\
\hline OC8. & Manages to expand the installed capacity whenever necessary & & & 0.594 & \\
\hline
\end{tabular}


The final factors displayed a reduction of the number of variables in each construct, resulting in six variables for the $D C$ construct, five for the MC, five for the OC, and four for the TC. The final instrument revealed a cumulative total variance explained for the four factors at $57.89 \%$, which is considered an acceptable result as it approximates 60\% (Malhotra, 2006). All variables exhibited high standardized loadings (i.e., > 0.5). The internal consistency was again confirmed, and Table 4 illustrates the results. It can be noted that the Cronbach's alpha coefficient has slightly decreased, but the total variance explained has increased

\section{Table 4. Comparing Cronbach's alpha: Full variables versus main factors}

\begin{tabular}{l|c|c}
\hline & 5-factor model & 4-factor model \\
\hline DC & 0.822 & 0.845 \\
\hline OC & 0.843 & 0.796 \\
\hline MC & 0.800 & 0.793 \\
\hline TC & 0.794 & 0.758 \\
\hline TOTAL & Alpha $=0.910$ & Alpha $=0.889$ \\
\hline KMO & 0.922 & 0.905 \\
\hline \% Cumulative 4 factors & $45.47 \%$ & $57.89 \%$ \\
\hline \% Cumulative 5 factors & $54.28 \%$ & - \\
\hline
\end{tabular}

The factor analysis confirmed the existence of an innovation capability model based on the firms' four capabilities: DC, OC, MC, and TC. We performed a factor analysis to generate the independent factors to perform a regression analysis using IP. Generating the independent variables through a factor analysis allows for constructs that are not correlated.

\section{Influence of innovation and dynamic capabilities on the firm's innovation performance}

Multiple regression analysis was conducted with the purpose of investigating the impact of the capabilities of the firm on its IP (Table 5).

Using a stepwise regression, the model's level of explanation is represented by the coefficient of the determinant $\mathrm{R}^{2}$, which is a measure of adjustment for the regression line, namely, the proportion of the variation in the dependent variable explained by the set of explanatory variables.

The adjusted $\mathrm{R}^{2}$ for the innovation capability model was 0.232 . Social science studies consider this value for the adjusted $\mathrm{R}^{2}$ as acceptable (Hair et al., 2005; Malhotra, 2006). Other authors have presented innovation capabilities models with $R^{2}$ values less than 0.210 (Guan \& Ma, 2003; Yam, Guan, Pun, \& Tang, 2004). Once the regression model's adequacy is tested, the following equation is defined:

$$
I P=0.04+0.311 M C+0.271 D C+0.236 T C+0.0940 C+e
$$

Based on this equation, it is possible to affirm that the dependent variable IP can be positively explained by the four capabilities in the innovation capability model, with an explanation rate of $23 \%$ of the total variance of the variable IP. This result confirms our hypothesis, in that all capabilities impact IP.

This result also suggests that other factors exist, such as the existing institutional framework, an ongoing environmental context, and the sectoral technological base, which will affect firms' IP. However, ceteris paribus for all firms in a given sector and market, any firm really must develop the four internal capabilities to be innovative.

The MC has the highest impact over the IP and thus the dynamics of the firms in our sample, followed by DC, then TC. The $O C$ is the capability with the lowest beta value. It may be noteworthy to mention the OC's role in these firms before we explore these other results. As the $O C$ has the lowest impact, we reaffirm some of the main characteristics of Brazilian firms, specifically, based in low-tech, and having an operational drive (Reichert et al., 2015). Most, in other words, operate mature technologies that have already achieved sufficient efficiency, and apparently do not need further innovation. Therefore, it is not the $\mathrm{OC}$ that will differentiate one firm from another in this context. While $O C$ is an ordinary capability, the MC, DC, and TC define the firm's dynamic capabilities.

Table 5. Regression analysis

\begin{tabular}{|c|c|c|c|c|c|}
\hline \multicolumn{6}{|c|}{ Coefficients $^{a}$} \\
\hline \multicolumn{6}{|l|}{$N=1,107$} \\
\hline \multirow{2}{*}{ Model } & \multicolumn{2}{|c|}{$\begin{array}{l}\text { Unstandardized } \\
\text { Coefficients }\end{array}$} & \multirow{2}{*}{\begin{tabular}{|c}
$\begin{array}{c}\text { Standardized } \\
\text { Coefficients }\end{array}$ \\
Beta
\end{tabular}} & \multirow{2}{*}{$\mathrm{t}$} & \multirow{2}{*}{ Sig. } \\
\hline & B & Std. Error & & & \\
\hline (Constant) & 0.004 & 0.028 & & 0.140 & 0.889 \\
\hline $\mathrm{DC}$ & 0.268 & 0.028 & 0.271 & $9 \cdot 515$ & 0 \\
\hline MC & 0.309 & 0.028 & 0.311 & 10.927 & 0 \\
\hline $\mathrm{OC}$ & 0.094 & 0.028 & 0.094 & $3 \cdot 321$ & 0.001 \\
\hline $\mathrm{TC}$ & 0.233 & 0.028 & 0.236 & 8.291 & 0 \\
\hline
\end{tabular}

aDependent variable: Innovation performance (IP) 


\section{Linking innovation and dynamic capabilities}

While economic and business literature widely discusses innovation as a main source of firms' long-term competitive advantage, a challenge remains in creating a model that accounts for the innovative firm's main features. The consensus seems to be that innovation is a result of the firm's capabilities to handle and influence constantly changing environment (Teece et al., 1997), which changes its resource base (Helfat et al., 2007). However, the dynamic capabilities framework as a theory often receives criticism for not offering an empirical model that can be tested (Ambrosini \& Bowman, 2009; Arend \& Bromiley, 2009; Barreto, 2010). Teece (2007) further notes the ambition in the dynamic capabilities framework "[...] is nothing less than to explain the sources of enterprise-level competitive advantage over time, and provide guidance to managers for avoiding the zero profit condition that results when homogeneous firms compete in perfectly competitive markets" (p. 1320).

We have advanced by building and testing a capabilitybased assessment model to verify the predictions theoretically expressed by the dynamic capabilities framework. Moreover, our model indicates how dynamic capabilities actually correlate to higher levels of innovative performance. Prior theory has posed that these capabilities are composed of many activities, and our results present the activities that were most relevant in terms of their impact on firms' innovation performance.

The $D C$ is a result of processes put in place in the firm, which allows it to develop new products and even new technology. These activities include prototyping products, the firm's launching and designing its own products, monitoring the latest technological trends, using such formal project management tools as Stage-Gate or PMBOK, and adapting existing technologies to the firm's own needs. This is a dynamic capability by nature, as it corresponds to the activities that involve sensing new technological and market opportunities and developing solutions for this market (Pisano, 2000; Teece, 2007; Teece et al., 1997). When the activities from these capabilities are regressed against our measures of IP, these place second in terms of its influence on innovation.

When we observe the $O C$ and its influence on firms' IP, the results indicated very little influence. This leads to the conclusion that its main focus is efficiency, as this capability is highly based on routine activities. As Teece (2007) notes, other firms may widely adopt these capabilities as "best practices," and they are unlikely to be considered dynamic capabilities. Helfat and Peteraf (2003) and Winter (2003) classify these as "ordinary capabilities." The $\mathrm{OC}$ was also less relevant in a complementary study on innovation capabilities, which focused on low-tech firms (Reichert, Torugsa, Zawislak, \& Arundel, 2016).

Our results showed that MC most influences the IP of the firms in our sample. According to Teece et al. (1997), when it focuses on coordination and integration, this capability seems to have a primarily static function of "putting things in order" by keeping its business model current, implementing management tools, or using modern financial techniques, among other functions. However, the $M C$ is regarded as a dynamic capability when involved in the task of "finding methods and procedures to peer through the fog of uncertainty and gain insight" (Teece, 2007, p. 1326). Moreover, management's ability to identify, develop, and utilize a combination of built or bought specialized and co-specialized assets is an important dynamic capability, but it is not always present in enterprise settings (Teece, 2007, p. 1338). Teece (2007) calls for entrepreneurial management to face the challenge of overcoming the efficiency paradox through coordination and dynamics. The $M C$ in our results to some extent counterintuitively presented the highest influence over innovation performance, which corroborates the premises found in the dynamic capabilities framework.

Finally, the ability to organize and decide firms' boundaries enters our model under the firm's TC. Theses have implied the market power in a giving firm, and its ability to impose its conditions on the market, such as prices and negotiation conditions to both clients and suppliers. The innovative firm is one with this type of market power, and gains Schumpeterian rents by creating and sustaining a unique position. This is also a dynamic capability; Teece et al. (1997) stresses that in globalized markets, the ability to orchestrate internal and external co-specialized assets and build valuable intangible ones, such as reputational assets, is another key firm feature to create and sustain competitive advantage.

Our study shows that development, management and transaction capabilities are the dynamic capabilities for innovation, and one should expect to find a higher impact than operations capabilities. Development, management and transaction capabilities encompass the capabilities needed to "do the right things" rather than the simple pursuit of "doing things right" (Teece, 2014). These efforts will depend much more on an existing set of products and how they are orchestrated into the market, than on operations itself, as regular operations based on predictable routines tend to reach for stability rather than dynamics and change.

\section{FINAL REMARKS}

Our findings offer an empirical assessment model that tests firms' dynamic capabilities and, therefore, better explains the sources of enterprise-level competitive advantage over time, to meet Teece's (2007) expectations. This is accomplished through a firm innovation capability model, as proposed by Zawislak et al. (2012) and Zawislak, Alves, Tello-Gamarra, Barbieux, and Reichert (2013). 
This model discovers important convergences that empirically support the theoretical assertions of the dynamic capabilities framework proposed by Teece et al. (1997). As dynamic capabilities are invisible and difficult to measure, this research provides some evidence of their existence. Moreover, it is a first step toward a comprehensive model of firms' innovation and dynamic capabilities. If we seek a more general explanation of the innovative firm's successes and failures, we must be able to discover the patterns of innovative activity throughout its innovation capabilities.

Our results demonstrated that the model's four capabilities do impact firms' innovative performance at different levels. OC appears to be the least dynamic of all with non-significant influence over innovation. This reinforces the notion that operations capabilities are actually “ordinary capabilities" (Teece, 2007; 2014; Winter, 2003). These are a sort of minimum competitiveness capabilities which are routine-based and less dynamic. One may perceive $O C$ as a means to operationalize industry standards for any given firm. Nevertheless, the firm must rely on the other three capabilities in order to bring about economic value from a given operation.

The MC presented the highest impact on firms' IP, which pairs with the higher emphasis given to entrepreneurial and managerial activities in the dynamic capabilities framework. Some firms may follow MC as the leading, main driver for innovation when they perform efficiently through the MC's integration and coordination innovations.

Amid these capabilities, DC and TC provide a final touch on the firms' innovation profiles. Some firms, and generally hightech ones, may focus more on R\&D and product development; therefore, they mainly innovate through their DC. Other firms, and normally those more attached to final markets, innovate through different combinations of transactional relations and innovate through their TC.

While our model attempts to find some patterns of capability behavior, this does not mean that all firms will perform these capabilities in the same manner or intensity. As noted by Nelson (1991) firms are inexorably different because of the internal knowledge that underlies its own set of routines and capabilities. However, by defining a broader scope of the relevant clusters of knowledge and capabilities need under what we called development, operations, management and transaction capabilities, one could attempt an "innovation and dynamic capabilities recipe" to predict and prescribe possible paths of innovation of given firms.

If, on the one hand, companies should search for and keep minimum levels of technical and operational structure and capability to perform the best practices possible, on the other, best practices will not cause substantial change and performance, as they exist to be followed. Innovation and dynamic capabilities are "higher order" capabilities (Wang \& Ahmed, 2007; Winter,
2003) responsible for creating the new standards and reshaping the competitive environment for others to follow. This can offer some explanation as to the competitiveness in firms and countries. Innovation primarily depends on the other three dynamic capabilities: the development, management, and transaction capabilities. These capabilities must constantly be nurtured and enhanced as the processes of "sensing, seizing and transforming" (Teece, 2007) occurs primarily through and across them in different levels. Our model helps to highlight and frame what are the dynamic capabilities needed to turn the internal and external novelty efforts into innovation.

\section{LIMITATIONS AND FUTURE RESEARCH}

This study has some limitations. While we proposed an assessment model based on four general capabilities we considered to be found in any firm, and were able test it relative to a Schumpeterian innovation-based economic performance, our results explain only $23.2 \%$ of the full phenomena, based on the $\mathrm{R}^{2}$ obtained in our regressions. Thus, many other elements exist that influence firms' ability to be dynamic and to innovate. Some of these other factors, such as institutions, technological bases, and the market, are external to the firm, to a large extent.

Nevertheless, we isolated the capabilities and routines to understand the fundamental features of innovation and dynamic capabilities. As we observed several sectors, future studies could explore whether the configuration of capabilities and their relative importance for innovation may change across sectors.

Finally, this model was conducted using Brazilian firms, which have peculiar industrial and dynamic features. Its replication in other industrial and organizational contexts may reveal different results and new insights.

\section{ACKNOWLEDGEMENTS}

The present study was carried out by the Innovation Research Center (Núcleo de Estudos em Inovação, NITEC) of the Federal University of Rio Grande do Sul (Universidade Federal do Rio Grande do Sul, UFRGS), with the financial support from the State of Rio Grande do Sul Research Foundation (Fundação de Amparo à Pesquisa do Estado do Rio Grande do Sul, FAPERGS) and the Brazilian National Council for Scientific and Technological Development (Conselho Nacional de Desenvolvimento Científico e Tecnológico, CNPq). 


\section{REFERENCES}

Ambrosini, V., \& Bowman, C. (2009). What are dynamic capabilities and are they a useful construct in strategic management? International Journal of Management Reviews, 11(1), 29-49. doi:10.1111/j.14682370.2008.00251.x

Arend, R., \& Bromiley, P. (2009). Assessing the dynamic capabilities view: Spare change, everyone? Strategic Organization, 7(1), 75-90. doi:10.1177/1476127008100132

Bain, J.S. (1956) Barriers to new competition. Cambridge, UK: Harvard University Press.

Barney, J. (1991). Firm resources and sustained competitive advantage. JournalofManagement,17(1),99-120.doi:10.1177/014920639101700108

Barreto, I. (2010). Dynamic capabilities: A review of past research and an agenda for the future. Journal of Management, 36(1), 256-280. doi:10.1177/0149206309350776

Bell, M., \& Pavitt, K. (1995). The development of technological capabilities: Trade, technology and international competitiveness. Economic Development Institute of the World Bank, 22(4831) 69-100.

Breznik, L., \& Hisrich, R. D. (2014). Dynamic capabilities vs. innovation capability: Are they related? Journal of Small Business and Enterprise Development, 21(3), 368-384. doi:10.1108/jsbed-02-2014-0018

Cannon, J., \& Homburg, C. (2001). Buyer-supplier relationships and customer firm costs. Journal of Marketing, 65(1), 29-43. doi:10.1509/ jmkg.65.1.29.18136

Chandler, A. D., Jr. (1977). The visible hand. Cambridge, USA, and London, England: The Belknap Press of Harvard University Press.

Churchill, G. A., Jr. (1979). A paradigm for developing better measures of marketing constructs. Journal of Marketing Research, 16(1), 64-73. doi:10.2307/3150876

Coase, R. (1937). The nature of the firm. Economica, 4(16), 386-405. doi:10.1111/j.1468-0335.1937.tboooo2.x

Dosi, G., Freeman, C., \& Nelson, R. (Eds.). (1988). Technical change and economic theory (Vol. 988). London, UK: Pinter.

Dosi, G., Nelson, R., \& Winter, S. (Eds.). (2000). The nature and dynamics of organizational capabilities. Oxford, UK: OUP.

Dutrénit, G. (2000). Learning and knowledge managerial in the firm: From knowledge accumulation to strategic capabilities. Northampton, UK: Edward Elgar.

Eisenhardt, K. M., \& Martin, J. A. (2000). Dynamic capabilities: What are they? Strategic Management Journal, 21(10-11), 1105-1121. doi:10.1002/10970266(200010/11)21:10/11/1105::aid-smj133/3.0.c0;2-e

Eriksson, T. (2014). Processes, antecedents and outcomes of dynamic capabilities. Scandinavian Journal of Management, 30(1), 65-82. doi:10.1016/j.scaman.2013.05.001

Francis, D., \& Bessant, J. (2005). Targeting innovation and implications for capability development. Technovation, 25(3), 171-183. doi:10.1016/j.technovation.2004.03.004
Freeman, C., Clark, J., \& Soete, L. (1982). Unemployment and technical innovation: A study of long waves and economic development. London, UK: Burns \& Oates.

Guan, J., \& Ma, N. (2003). Innovative capability and export performance of Chinese firms. Technovation, 23(9), 737-747. doi:10.1016/So1664972(02)00013-5

Hair, J. F., Tatham, R. L., Anderson, R. E., \& Black, W. C. (2005). Análise multivariada de dados ( $5^{\text {a }}$ ed.). Porto Alegre, RS: Bookman.

Hayes, R. H., \& Pisano, G. P. (1994). Beyond world-class: The new manufacturing strategy. Harvard Business Review. Retrieved from https://hbr.org/

Helfat, C. E., Finkelstein, S., Mitchell, W., Peteraf, M., Singh, H., Teece, D., \& Winter, S. G. (2007). Dynamic capabilities: Understanding strategic change in organizations. Maldem, MA: Blackwell Publishing.

Helfat, C. E., \& Peteraf, M. A. (2003). The dynamic resource-based view: Capability lifecycles. Strategic Management Journal, 24(10), 9971010. doi:10.1002/smj.332

Kline, R. B. (1998). Principles and practice of structural equation modeling. New York, USA: The Guilford Press.

Kotabe, M., Srinivasan, S. S., \& Aulakh, P. (2002). Multinationality and firm performance: The moderating role of R\&D and marketing capabilities. Journal of International Business Studies, 33(1), 79-97.

Lall, S., 1992. Technological capabilities and industrialization. World Development, 20(2), 165-186. doi:10.1016/0305-750X(92)90097-F

Langlois, R. N. (2003). The vanishing hand: The changing dynamics of industrial capitalism. Industrial and Corporate Change, 12(2), 351385. doi:10.1093/icc/12.2.351

Malhotra, N. (2006). Pesquisa de marketing: Uma orientação aplicada ( $4^{\mathrm{a}}$ ed.). Porto Alegre, RS: Bookman.

Mayer, K., \& Salomon, R. (2006). Contract design as a firm capability: An integration of learning and transaction cost perspectives. Academy of Managerial Review, 49(5), 942-959.

Mintzberg, H. (1973). The nature of managerial work. New York, USA: Harper \& Row.

Nelson, R. R. (1991). Why do firms differ, and how does it matter? Strategic Management Journal, 12(S2), 61-74. doi:10.1002/smj.4250121006

Nelson, R. R., \& Winter, S. G. (1982). An evolutionary theory of economic change. Cambridge, MA: Belknap Press of Harvard University Press.

Núcleo de Gestão da Inovação Tecnológica. (2015). Caminhos da inovação na indústria gaúcha. Retrieved from http://www.ufrgs.br/ nitec/wp-content/uploads/2015/12/revista_inova.pdf

Organisation for Economic Co-operation and Development. (2005). Oslo Manual: Guidelines for collecting and interpreting innovation data, 3rd Edition, OECD Publishing, Paris, France. doi:10.1787/9789264013100-en

Penrose, E. (1959). The theory of the growth of the firm. New York, USA: Oxford University Press.

Pestana, M. H., \& Gageiro, J. N. (2003). Análise de dados para ciências sociais: A complementaridade do SPSS (3rd.). Lisboa, Portugal: Sílabo.

Pisano, G. P. (2000). In search of dynamic capabilities: The origins of $R \& D$ competence in biopharmaceuticals (pp. 129-154). Oxford, USA: Oxford University Press.

Porter, M. E. (1985). Competitive advantage: Creating and sustaining superior performance. New York, USA: FreePress. 
Prahalad, C., \& Hamel, G. (1990). The core competence of the corporation. Harvard Business Review, 68(3). Retrieved from https://hbr.org/

Pufal, N. A., Zawislak, P. A., Alves, A. C., \& Tello-Gamarra, J. (2014). Management capability and the paradox of the organized firm. Strategic Management Quarterly, 2(3-4), 47-69. doi:10.15640/smq. v2n3-4a3

Reichert, F. M., Camboim, G. F., \& Zawislak, P. A. (2015). Capacidades e trajetórias de inovação de empresas brasileiras. RAM-Revista de Administração Mackenzie, 16(5), 161-194. doi:10.1590/167869712015/administracao.v16n5p161-194

Reichert, F. M., Torugsa, N. A., Zawislak, P. A., \& Arundel, A. (2016). Exploring innovation success recipes in low-technology firms using fuzzy-set QCA. Journal of Business Research, 69(11), 5437-5441. doi:10.1016/j.jbusres.2016.04.151

Richardson, G. (1972). The organisation of industry. Economic Journal, 82(327), 883-896. doi:10.2307/2230256

Rosenberg, N. (1982). Inside the black box: Technology and economics. New York, USA: Cambridge University Press.

Schumpeter, J. A. (1934). The theory of economic development: An inquiry into profits, capital, credit, interest, and the business cycle (Vol. 55). Piscataway, USA: Transaction Publishers.

Shafia, M. A., Shavvalpour, S., Hosseini, M., \& Hosseini, R. (2016) Mediating effect of technological innovation capabilities between dynamic capabilities and competitiveness of research and technology organisations. Technology Analysis \& Strategic Management, 28(7), 1-16. doi:10.1080/09537325.2016.1158404

Skinner, W. (1969). Manufacturing: Missing link in corporate strategy. Harvard Business Review, 47(3). Retrieved from https://hbr.org/

Snow, C. C., \& Hrebiniak, L. G. (1980). Strategy, distinctive competence, and organizational performance. Administrative Science Quarterly, 25(2), 317-336. doi:10.2307/2392457

Teece, D. J. (1986). Profiting from technological innovation: Implications for integration, collaboration, licensing and public policy. Research Policy, 15(6), 285-305. doi:10.1016/0048-7333(86)90027-2

Teece, D. J. (2007). Explicating dynamic capabilities: The nature and microfoundations of (sustainable) enterprise performance. Strategic Management Journal, 28(13), 1319-1350. doi:10.1002/smj.640

Teece, D. J. (2010). Technological innovation and the theory of the firm: The role of enterprise-level knowledge, complementarities, and (dynamic) capabilities. Handbook of the Economics of Innovation, 1, 679-730.
Teece, D. J. (2014). The foundations of enterprise performance: Dynamic and ordinary capabilities in an (economic) theory of firms. The Academy of Management Perspectives, 28(4), 328-352. doi: 10.5465/amp.2013.0116

Teece, D., Pisano, G., \& Shuen, A. (1997). Dynamic capabilities and strategic managerial. Strategic Managerial Journal, 18(7), 509-533. doi:10.1002/ (sici)1097-0266(199708)18:7く509::aid-smj882〉3.0.c0;2-z

Tello-Gamarra, J. E., \& Zawislak, P. A. (2013). Transactional capability: Innovation's missing link. Journal of Economics, Finance \& Administrative Science, 18(34), 2-8. doi:10.1016/S2077-1886(13)70017-9

Trott, P. (2008). Innovation management and new product development. Harlow, UK: Prentice-Hall.

Vicente, M., Abrantes, J. L., \& Teixeira, M. S. (2015). Measuring innovation capability in exporting firms: The INNOVSCALE. International Marketing Review, 32(1), 29-51. doi:10.1108/IMR-09-2013-0208

Wang, C. L., \& Ahmed, P. K. (2007). Dynamic capabilities: A review and research agenda. International Journal of Management Reviews, 9(1), 31-51. doi:10.1111/j.1468-2370.2007.00201.x

Ward, P., McCreery, J., Ritzman, L., \& Sharma, D. (1998). Competitive priorities in operations management. Decisions Science, 29(4), 10351046. doi:10.1111/j.1540-5915.1998.tboo886.x

Wernerfelt, B. (1984). A resource-based view of the firm. Strategic Management Journal, 5(2), 171-180. doi:10.1002/smj.4250050207

Williamson, O. (1985). The economic institutions of capitalism. New York, USA: Free Press.

Winter, S. G. (2003). Understanding dynamic capabilities. Strategic Management Journal, 24(10), 991-995. doi:10.1002/smj.318

Wu, S. J., Melnyk, S. A., \& Flynn, B. B. (2010). Operational capabilities: The secret ingredient. Decision Sciences, 41(4), 721-754. doi:10.1111/ j.1540-5915.2010.00294.x

Yam, R., Guan, J. C., Pun, K. F., \& Tang, E. P. (2004). An audit of technological innovation capabilities in Chinese firms: Some empirical findings in Beijing, China. Research Policy, 33(8), 11231140. doi:10.1016/j.respol.2004.05.004

Zawislak, P. A, Alves, A. C., Tello-Gamarra, J., Barbieux, D., \& Reichert, F. M. (2012). Innovation capability: From technology development to transaction capability. Journal of Technology Management \& Innovation, 7(2), 14-27. doi:10.4067/S0718-27242012000200002

Zawislak, P. A, Alves, A. C., Tello-Gamarra, J., Barbieux, D., \& Reichert, F. M. (2013). Influence of internal capabilities of firms on their innovation performance: A case study investigation in Brazil. International Journal of Management, 30(1), 329-348. 